\title{
FREIGHT RAILWAY TRANSPORT: CRITICAL VARIABLES TO IMPROVE THE TRANSPORT APPLIED TO INFRASTRUCTURE COSTS AND ITS ASSOCIATED TRAFFIC FLOW
}

\author{
Juan de Dios Sanz Bobi \\ Maria Luisa Martínez Muneta \\ Miguel Sanz López
}

Mechanical Engineering Department. Universidad Politecnica de Madrid. Spain

\begin{abstract}
The developed societies have as challenge, among others, to achieve a mobility development based on economic models of low carbon and energy efficient, making it accessible to the entire population. In this context, the sustainable mobility seems to meet the economic, social and environmental needs, minimizing their negative impact. There are three factors that are relevant: (1) infrastructures; (2) modes of transport more ecological and safe, and (3) operations and services for passengers and freights.
\end{abstract}

The objective of this research is to provide guidance to investment in sustainable transport infrastructures that are truly useful and effective. In particular we have studied the case of the railway, using the following information: details of the infrastructure; cost of construction (per kilometre); maintenance cost, and life cycle. This information may be relevant to consider their possible business models.

The methodology of this research was focused in the detailed analysis of the infrastructure use and maintenance criteria, the market opportunities for freight development and the available data to validate the obtained results from the software tool reached in this work. Our research includes the different following aspects:

- Evaluation of the supported traffic by the rail line.

- Relevant items to be considered in the rail infrastructure. Defining the track, we can group items in two sets: civil and rail installations.

- Rolling stock available. Locomotives and wagons are modelled to introduce the data as convenience for the user.

Besides our research includes the development of software, Decision System Tool (DST), for studying the construction and maintenance cost of railway infrastructure. It is developed in a common and open source program, providing the user the interaction with the critical variable of the line. It has been adjusted using the following references: MOM PlanCargorail; EcoTransIT, and Projects funded by Framework Program of EU (NewOpera, Innotrack and Sustrail).

\section{BACKGROUND}

\subsection{Framework}


The railway in Spain has been a breakthrough in terms of civil use for passenger transport, especially with regard to high speed. This has allowed decongest conventional lines that can be better used for transporting goods.

However freight, where the railroad has hardly developed, has not been involved in technological improvements applied to passenger transport. However, the Spanish rail network is starting to grow thanks to increased investment in infrastructure, which in 2011 reached a figure of 7580 million Euros, representing $50.4 \%$ of total investments in infrastructure, $49.6 \%$ being in other modes of transport.

According to the "Observatorio del Ferrocarril", transport of goods by rail increased by $12.3 \%$ traffic net tons and $11.8 \%$ in tonne-kilometres in 2011 compared to 2010. However revenues marked a $8.8 \%$ decrease.

These data indicate that there is a timid growth of rail freight, but in relation to road transport remains a big gap. In 2010 the percentage of goods transported by rail accounted for $4.2 \%$ of the total in Spain, while the average in the EU was $14.9 \%$, with $79.9 \%$ the transported by road. It is a very large difference indicates that in other European countries if they are betting more for rail freight transport.

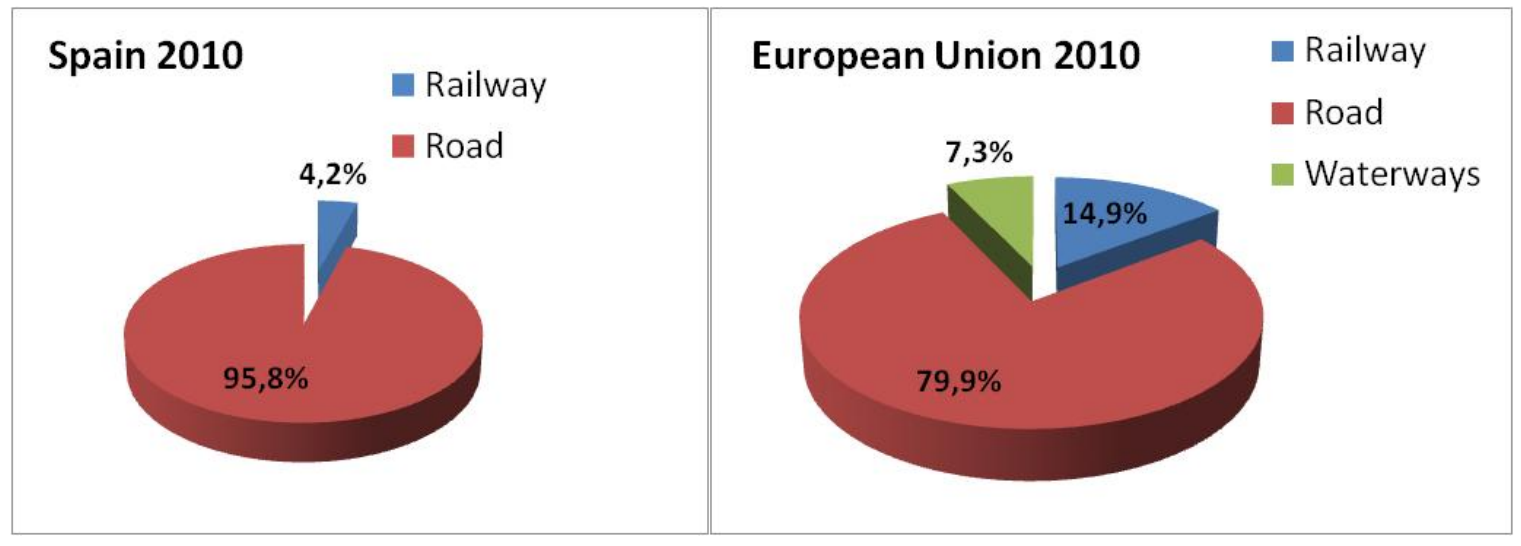

Figure 1. Distribution of goods in different modes of transport.

International Railways Union " 2010 Report on Combined Transport "

One of the causes for wanting to improve rail freight sector is primarily the rising price of oil, because Europe is not producing region (except for some isolated cases). This causes the balance of payments of the countries of the European Union to become unbalanced. Another motivation is to reduce emissions, particularly $\mathrm{CO}_{2}$. If the freight is oriented to electrified railway and with an energy mix oriented towards renewable can get a very low rate of $\mathrm{CO}_{2}$ emissions associated with this activity. Spain is a country that should bet on renewable energies in the short term, as has the technology and skills needed to exploit it. Within the freight market competition among enterprises it has evolved in recent years, causing the customer requirements demand have also evolved, thereby creating the need to create new quality products and competitive. In the current rail transport market there is an almost monopolistic situation arising from previous periods that has not allowed the development of the sector and has prevented this mode of transport is taken into account as an alternative to road transport. 


\subsection{Freight rail sector}

In the Spanish market, we see that the investments have been especially dedicated to the civil railway sector, leaving a little aside the transport of goods by rail. This lack of dedication , accompanied by the preference of customers for transport by road sector has caused a decline in freight transport by rail. The main problem with this mode of transport is its lack of competitiveness due to its lack of flexibility and price . It is therefore important to look for those improvements that can reduce the costs of rail freight, which research in this article aims to give clues to what might be the measures to be taken.

\section{MODEL CONSTRUCTION}

\subsection{Main data}

To make the model we have taken a particular route , Valencia - Bilbao. This makes the data can serve as a general approach for other cases, but keep in mind that there are certain conditions that may be differentiators such as the topography of the route.

In the study it was decided to consider that the trains are composed of container wagons , so you can make a more direct comparison with the transport of goods by road. The chosen wagon is the model RENFE MMC3E with the features shown in the following table.

\begin{tabular}{|l|l|l|l|l|l|}
\hline Denomination & $\begin{array}{l}\text { Maximum } \\
\text { speed }\end{array}$ & Axels & Tare & Load & Length \\
\hline MMC3E & $100 \mathrm{~km} / \mathrm{h}$ & 4 & $19,7 \mathrm{t}$ & $70,3 \mathrm{t}$ & $19,74 \mathrm{~m}$ \\
\hline
\end{tabular}

Table 1. Characteristics of the wagon MMC3E.

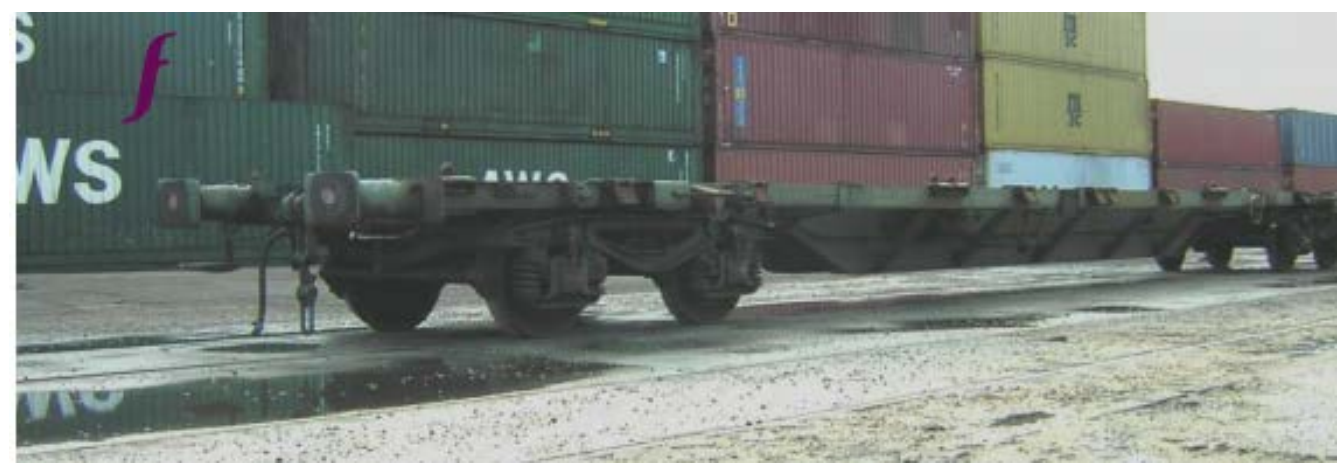

Figure 2. Wagon MMC3E.

They have also been considered two types of locomotives, electric and diesel, so that allow us to study the costs of both types of traction.

In the case of electric locomotive we have chosen RENFE 253 model, which has a total power of 7,337 hp and a traction boot effort of $300 \mathrm{kN}$.

The diesel locomotive chosen is the model 335 RENFE, with a total power of 4,320 hp and 
effort to start tract of $400 \mathrm{kN}$.

For calculation of the maximum load towable have been considered different mechanical constraints to be respected such as peel strength, maximum effort boot, hook maximum effort and adherence to boot.

Thus, in addition to adding the maximum size limitation of the way, we get the train composition.

Among the data to be considered in the model, we have considered the costs associated with the acquisition of locomotives and wagons, as well as depreciation and driver wages expenses. Have also been considered energy costs, which are associated with the calculations along the sections of the course studied, so we have calculated the resistance to the advance on each of the distances that runs the train along each of the sections.

Finally, also considered Adif costs applicable to our study, and the possible movement in the two schedules established Adif, each with a different rate.

\subsection{Variables studied}

When assessing the costs of freight by rail we have defined a number of variables that will allow us to play different scenarios in which we develop our study.

These variables can be modified to study different cases and situations and see their impact on the various costs.

Variables that can be modified are as follows : Traction (Electric, Diesel), Schedules (Normal, Prime time), Tare , Energy consumption , Adif costs (Canon , Complementary Services and Auxiliary Services).

The results we get in our model will be the following costs: Cost (cnt $€ / t . k m)$, Adif Cost (cnt €/t.km), Rolling Stock Cost (cnt €/t.km).

\subsection{Using the model}

The model was made using a spreadsheet that has allowed us to operate all the above mentioned data for the various cost tables for each of the scenarios studied. We studied four different cases, each corresponding to a type of traction and at a different schedule, so that cases are as follows :

- Case 1 : Electric traction and normal schedule

- Case 2 : Diesel traction and normal schedule

- Case 3 : Electric traction and prime time

- Case 4 : Diesel traction and prime time

In each of these cases have tested different configurations of the variables mentioned above (tare, energy consumption, Adif costs). Each of these variables have been considered with variations no greater than $5 \%$.

\section{RESULTS}

After entering the data for each case and make changes of the variables we obtain the following summary tables . 


\begin{tabular}{|l|r|r|r|r|}
\cline { 2 - 5 } \multicolumn{1}{c|}{} & \multicolumn{4}{c|}{ Tare } \\
\cline { 2 - 5 } \multicolumn{1}{c|}{} & Case 1 & Case 2 & Case 3 & Case 4 \\
\cline { 2 - 5 } \multicolumn{1}{c|}{} & $-5 \%$ & $-5 \%$ & $-5 \%$ & $-5 \%$ \\
\hline Adif Cost (cnt $€ /$ t.km) & $-0,386 \%$ & $-0,498 \%$ & $-0,375 \%$ & $-0,488 \%$ \\
Rolling Stock Cost (cnt $€ / t . k m)$ & $-0,083 \%$ & $-0,26 \%$ & $-0,065 \%$ & $-0,21 \%$ \\
Emision $(\mathrm{g} / \mathrm{t} . \mathrm{km})$ & $-0,423 \%$ & $-0,521 \%$ & $-0,423 \%$ & $-0,521 \%$ \\
& $-1,337 \%$ & $-1,308 \%$ & $-1,337 \%$ & $-1,308 \%$ \\
\hline
\end{tabular}

Table 2. Summary of cost variation depending on the variation of the tare.

\begin{tabular}{|l|r|r|r|r|}
\cline { 2 - 5 } \multicolumn{1}{c|}{} & \multicolumn{4}{c|}{ Energy Consumption } \\
\cline { 2 - 5 } \multicolumn{1}{c|}{} & \multicolumn{1}{c|}{ Case 1 } & Case 2 & Case 3 & \multicolumn{1}{c|}{ Case 4 } \\
\cline { 2 - 5 } & $-5 \%$ & $-5 \%$ & $-5 \%$ & $-5 \%$ \\
\hline COST (cnt $€ / \mathrm{t} . \mathrm{km})$ & $-1,468 \%$ & $-1,904 \%$ & $-1,425 \%$ & $-1,865 \%$ \\
Adif Cost $(\mathrm{cnt} € / \mathrm{t} . \mathrm{km})$ & $-0,31 \%$ & $-0,994 \%$ & $-0,242 \%$ & $-0,803 \%$ \\
Rolling Stock Cost $(\mathrm{cnt} € / \mathrm{t} . \mathrm{km})$ & $-1,61 \%$ & $-1,991 \%$ & $-1,61 \%$ & $-1,991 \%$ \\
Emision $(\mathrm{g} / \mathrm{t} . \mathrm{km})$ & $-5 \%$ & $-5 \%$ & $-5 \%$ & $-5 \%$ \\
\hline
\end{tabular}

Table 3. Summary of cost variation depending on the variation in consumption.

\begin{tabular}{|l|r|r|r|r|}
\cline { 2 - 5 } \multicolumn{1}{c|}{} & \multicolumn{4}{c|}{ Adif Costs } \\
\cline { 2 - 5 } \multicolumn{1}{c|}{} & \multicolumn{1}{c|}{ Case 1 } & Case 2 & Case 3 & \multicolumn{1}{c|}{ Case 4 } \\
\cline { 2 - 5 } \multicolumn{1}{c|}{ COST (cnt $€ / \mathrm{t} . \mathrm{km})$} & $-5 \%$ & $-5 \%$ & $-5 \%$ & $-5 \%$ \\
Adif Cost (cnt $€ / \mathrm{t} . \mathrm{km})$ & $-0,545 \%$ & $-0,438 \%$ & $-0,676 \%$ & $-0,53 \%$ \\
Rolling Stock Cost $(\mathrm{cnt} € / \mathrm{t} . \mathrm{km})$ & $-5 \%$ & $-5 \%$ & $-5 \%$ & $-5 \%$ \\
Emision $(\mathrm{g} / \mathrm{t} . \mathrm{km})$ & $0,00 \%$ & $0,00 \%$ & $0,00 \%$ & $0,00 \%$ \\
\hline
\end{tabular}

Table 4. Summary of varying costs depending on the variation in costs of Adif.

Viewing Table 4 we can see that the only thing of value we get is the total cost, as others are quite trivial. In addition the costs of rolling stock, as well as emissions are not related to Adif costs.

Where we get some data of interest it is the total cost. We see the cost is greater variation in case 3 , case in which the traction is electric and the schedule is prime time. In this case there is a more significant change than in the other cases, so that differs around a $0.1 \%$ increase in absolute value compared to following case occurs. That is, the variation affects Adif costs much more to case 3 both positively and negatively.

However, case 2 (diesel traction and normal schedule) is the least affected by a variation of the Adif costs. This is because the management costs of fuel supply are lower than the supply of electricity. 
We can see that in case 1 and 4 variations are very similar, which indicates that the differences between traction and schedule are damped. In case 1 the traction is electric, which means we have Adif costs higher due to power management while the schedule is normal, which has lower cost. In case 4 is the opposite. The supply management costs are lower when dealing with diesel traction while schedule costs are higher when prime time. Turning to Table 2, the variation of costs with respect to the variation of the tare, we can see that no change at all costs.

In relation to the total cost, the case most affected by the variation of the tare is the case 2 (Diesel traction and normal schedule) although the case 4 (Diesel traction and prime time) presents similar variations. We can see that cases 2 and 4 show greater variation in costs because diesel traction is more sensitive to variations of the tare in terms of costs. Noting other data we can deduce the reason affects the tare more to Diesel traction than to the electric traction. The schedule has little influence on the costs when the tare varies.

If you look at the other two costs, which presents the most significant differences between cases is the cost of Adif, as the difference between the different tractions an increase around $0.2 \%$. In the case of rolling stock cost difference is $0.1 \%$ among cases with different traction.

This may be because the Diesel traction needs Adif complementary services that do not need electric traction, such as dispensing fuel. Therefore, a variation of the tare produces a variation in energy consumption, which in turn causes a variation in ADIF costs related to the supply of fuel.

In the case of emissions, we will see that they are directly related to energy consumption. Therefore as a variation of the tare produces a variation in consumption, we see emissions also vary. The variation is approximately a quarter of the variation of the tare.

As we see, the variables influencing not only costs, but also affect other variables. They could make numerous tables with different results for each of the interactions that might have a variable spare the others, but is not the object of this research, as it aims to present an approximation of the impact of variables on costs.

Lastly, analyzing the data presented in Table 3, we can see results already discussed above. The variation in energy consumption will have more significant variations in the case of diesel traction, as already seen in Table 2. The reasons are the same, but in this case are more evident because the variation ADIF costs is increased due to greater variation in consumption. Since in Table 2 tare variation not influence directly as consumption. One thing that we see is the 1: 1 relationship between the change in consumption with respect to the change in emissions, as these are linearly related to consumption. 


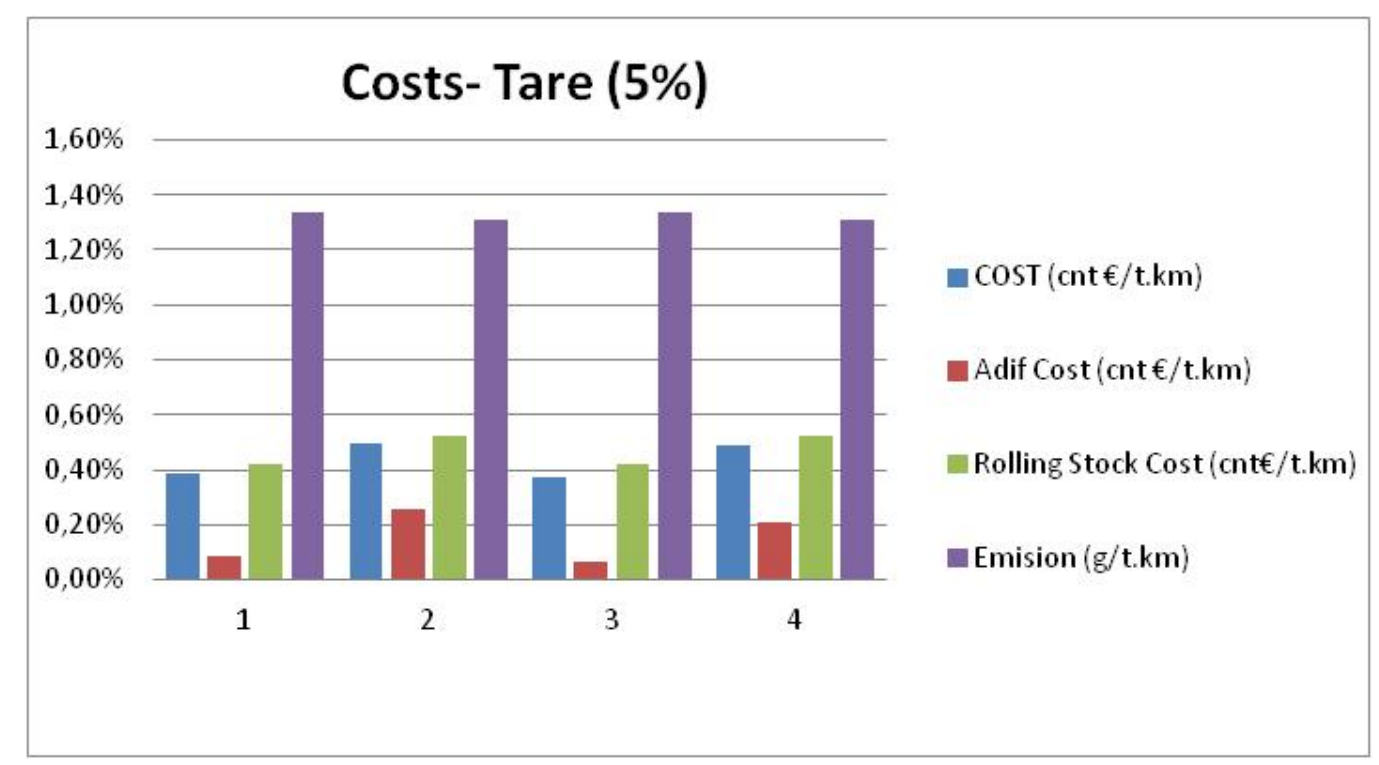

Figure 3. Variation in costs compared to a $5 \%$ variation of the tare.

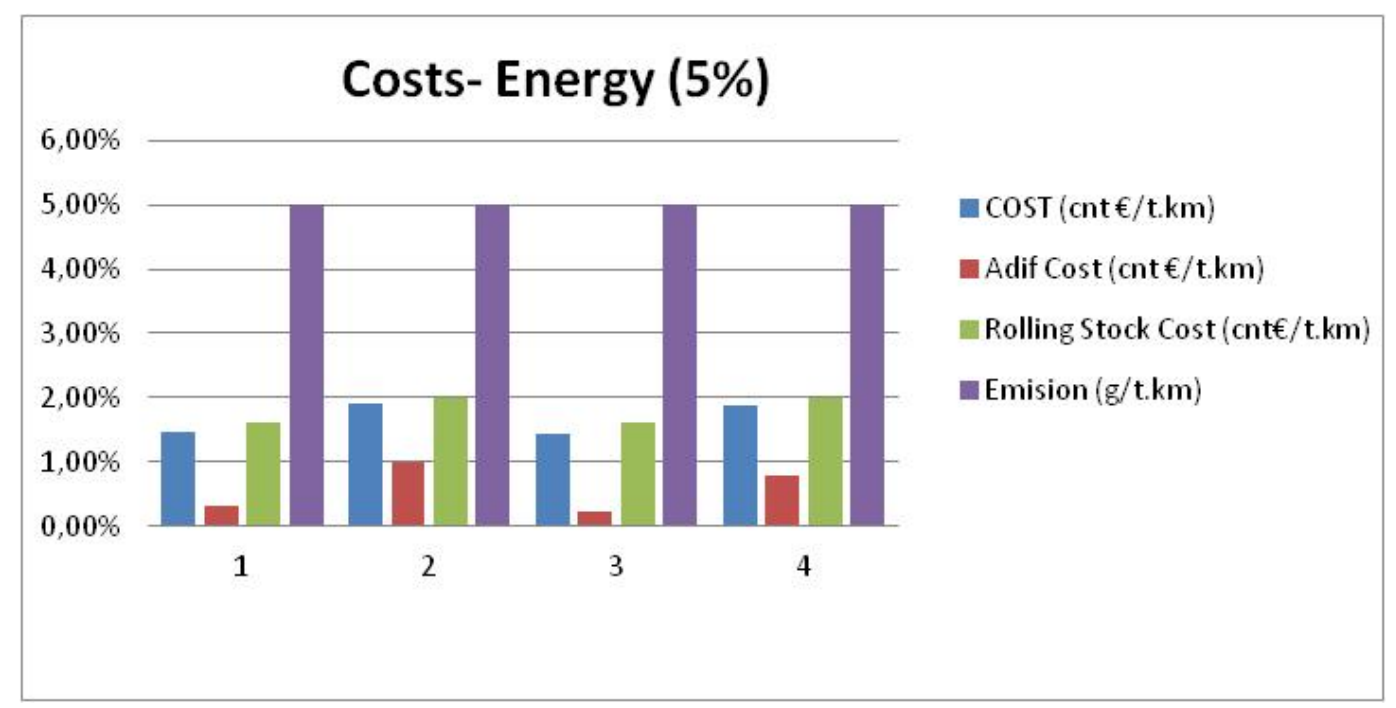

Figure 4. Changes in costs compared to a variation of $5 \%$ of energy consumption.

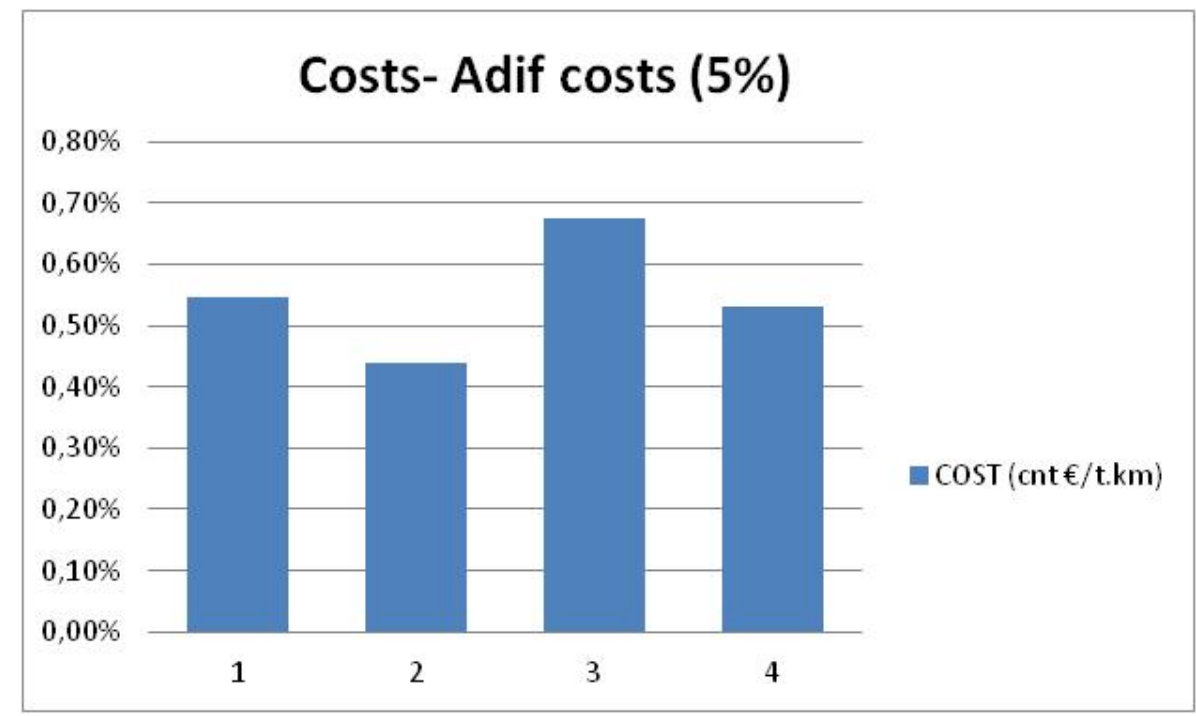

Figure 5. Variation of costs compared to a $5 \%$ variation ADIF costs. 


\section{COMPARATIVE STUDY OF FREIGHT TRANSPORT BY RAIL AND ROAD TRANSPORT}

To carry out this comparison has been used ACOTRAM tool, provided by the Ministry of Public Works. This tool allows us to calculate automatically the associated costs of freight road to compare them with those obtained by our model.

So we've used the case of articulated vehicle container (420 hp, MMA $=44,000 \mathrm{~kg}$ and payload $=26,250 \mathrm{~kg}$ ), obtaining the following table:

\begin{tabular}{|c|c|c|}
\hline & \multicolumn{2}{|c|}{ COSTES DIRECTOS ANUALES } \\
\hline & Euros $(€)$ & Distribución (\%) \\
\hline Costes directos & $115.768,46$ & $100,0 \%$ \\
\hline Costes por tiempo & $62.248,44$ & $53,8 \%$ \\
\hline Amortización del vehículo & $9.792,55$ & $8,5 \%$ \\
\hline Financiación del vehículo & 736,44 & $0,6 \%$ \\
\hline Personal de conducción & $31.411,76$ & $27,1 \%$ \\
\hline Seguros & $7.144,65$ & $6,2 \%$ \\
\hline Costes fiscales & $1.011,04$ & $0,9 \%$ \\
\hline Dietas & $12.152,00$ & $10,5 \%$ \\
\hline Costes kilométricos & $53.520,02$ & $46,2 \%$ \\
\hline Combustible & $41.236,36$ & $35,6 \%$ \\
\hline Neumáticos & $7.113,66$ & $6,1 \%$ \\
\hline Mantenimiento & $2.070,00$ & $1,8 \%$ \\
\hline Reparaciones & $3.100,00$ & $2,7 \%$ \\
\hline kilometraje anual (km / año) & 100.000 & \\
\hline kilometraje anual en carga (km / año) & 85.000 & \\
\hline Costes unitarios & & \\
\hline Costes directos ( $€ / \mathrm{km}$ recorrido) & 1,158 & \\
\hline Costes directos ( $€$ / km cargado) & 1,362 & \\
\hline
\end{tabular}

Table 5. Costs of freight with Container truck.

According to the above data, we have that road transport has a cost of $1.158 € / \mathrm{km}$ travelled and $1.362 € / \mathrm{km}$ in charge. In order to make a comparison with rail transport, we will calculate the perception of cost in units of $\mathrm{cnt} € / \mathrm{t} . \mathrm{km}$. The travel that would make a truck from Bilbao to Valencia consist of $611 \mathrm{~km}$ travelled through the AP-68 and A-23, with a cost of toll of $67.6 €$ for heavy vehicle type 2. The truck has an estimated distance of about $100,000 \mathrm{~km} /$ year. Of these total kilometres, would make $85 \%$ load. Therefore, doing the calculations between the distance of each journey and kilometres travelled per year in charge, we can estimate an activity of about 139 travels a year. The total cost ACOTRAM gives us is $115.768,46 €$. The cost associated with each travel, also due to adding the toll is $899.77 €$. Each truck can carry a payload of 26.25 t, which makes the cost per tonne is $34.28 €$, leaving the perception of cost $0.05609 \mathrm{cnt} € / \mathrm{t} . \mathrm{km}$. Below is a table with the data calculated for each of the cases exposed. 


\begin{tabular}{|l|c|c|c|c|}
\hline & $\begin{array}{l}\text { Maximum } \\
\text { load }\end{array}$ & Cost $(€ / \mathrm{km})$ & $\begin{array}{l}\text { Perception } \\
(\mathrm{cnt} € / \mathrm{t} . \mathrm{km})\end{array}$ & $\begin{array}{l}\text { \% empty } \\
\text { wagon }\end{array}$ \\
\hline Railway & 70,3 & 8,91 & 1,3 & 30 \\
\hline Truck & 26,25 & 1,362 & 5,61 & 15 \\
\hline
\end{tabular}

Table 6. Comparison of costs of road and rail transport.

\subsection{Analysis of results}

With the previously presented data we can draw some conclusions that can be useful.

To begin, we see that the cost in terms of $€ / \mathrm{km}$ is less in the case of road transport than in the case of rail transport. This is because no account is taken of the load factor, which is much higher in rail case. Without stating the load it is clear that the cost of the truck is lower, since spending on rolling stock and infrastructure are much lower.

When we consider the load transported to calculate the perception of cost, we realize the usefulness of rail transport. Such transport allows a single journey much more burden which can transport in a truck. Considering that the maximum load of a truck is $26.25 \mathrm{t}$ and a wagon is $70.3 \mathrm{t}$.

It has estimated the cost depending on the load for the rail and truck. In the case of rail it is assumed that the load determines the number of train wagons therefore to low load transported less wagons we need. Similarly, in the case of the truck, it is assumed that the load conditions the number of trucks used for transport. To do so in an analogous way, assume that the path must do it at once, that is, that for transporting for example 50 tons of cargo will be necessary in the case of the train, a single wagon, and in the case of the truck should be carry two of them.

Following the hypothesis made earlier come to obtain the following data that make up the graph.

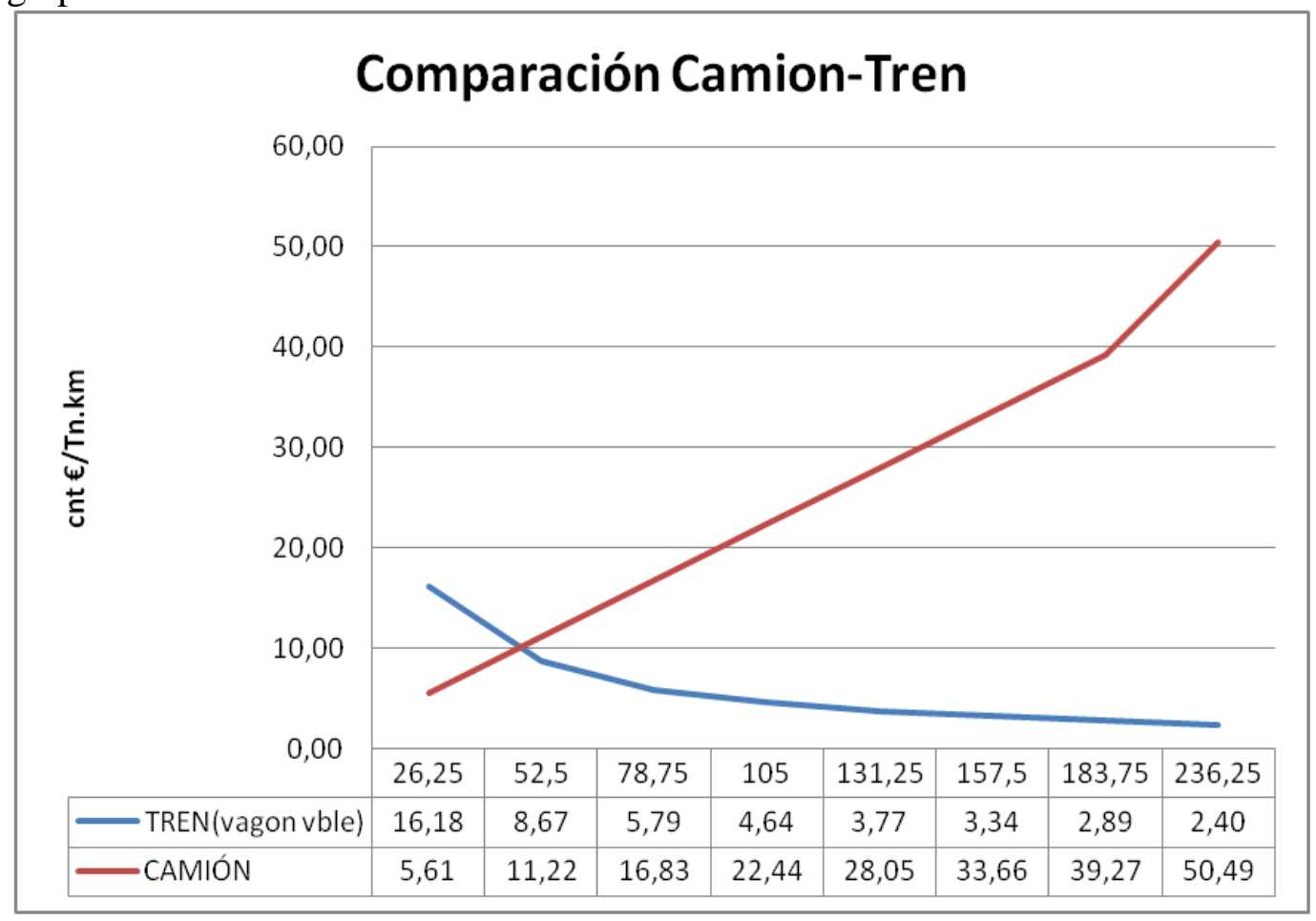

Figure 6. Comparison Chart perception in each mode of transport.

In Figure 6 we can see the data. On the horizontal axis is set to transport the load on the 
vertical axis and the perception of cost for that load. The graph shows that the load from which the cost per tonne and kilometre is equal is around $50 \mathrm{t}$. From which cost in the case of the truck hit the cost of the railway.

This is because in the case of rail, to carry more cargo, costs are increased to a lesser extent the burden we carry, which makes the perception of cost is diminishing as we increase the burden. In the case of truck, the costs increase if we have a greater load because it would be required to add trucks, with their respective drivers. This makes the cost increase to a greater extent than in the case of the train.

If the chart was accurate, more cost study points associated with the load, we could see some spikes in which the cost increase due to the inclusion of a new car or a new truck.

In conclusion we can see that to carry heavy loads over long distances we are interested in economic terms to use the railway. However at present, road transport is used because of its greater flexibility and the ability to go door to door.

Besides being favourable case railroad in economic terms, so is environmental terms.

The greater energy efficiency also translates into lower fuel consumption in litres. This is a great point in favour of the railway system. This entails a cleaner transport with lower emissions. If further traction used is diesel, this advantage increases in importance.

On average a truck consumes $36 \mathrm{l}$ per $100 \mathrm{~km}$. With a load of $25 \mathrm{t}$, it translates into $1.44 \mathrm{l}$ per tonne per 100 kilometres. With the classic approach of diesel locomotives consumption ( $4.5 \mathrm{l} / \mathrm{km}$ to tow $800 \mathrm{t}$ ), the result is $0.56 \mathrm{l}$ per tonne per 100 kilometres.

The railroad consumes 2.5 times less fuel than road transport. This also translates to the same extent in reducing emissions of polluting gases.

\section{CONCLUSIONS}

After analyzing all the data, we can see that rail transport is an option that should be taken into account. It is true that investments are high, and flexibility is more limited than in other modes of transport, but has great advantages such as high load capacity of the trains and lower emissions of greenhouse gases.

After seeing the different variables involved in rail transport, we note that the energy consumption has the most weight of the total cost. Since we can not intervene in energy prices, it could act on the consumption of locomotives and make them more efficient. Moreover, as seen above, consumption is related to the tare of the wagons. Making these lighter we could choose between two options. The first would reduce the energy consumption of locomotives due to reduced overhead. The second would be to translate that weight reduction wagons to increase the maximum load of trains. Thus we could carry more load at the same cost.

Adif costs are not as large in the total cost as having influence rolling stock. However, reducing infrastructure costs could also improve freight transport costs by rail to make it more competitive.

But despite all the improvements that can be introduced in rail transport, to promote this mode of transport, it would be necessary actions on a larger scale. They should minimize the problems of not being flexible transport mode, such as setting up logistics platforms in strategic locations where load would be transferred to other modes of transport. I would look for the balance between time and cost of transporting the load.

In comparison with road transport we have seen that in the case of needing two container trucks to transport the goods, the perception of the cost per ton kilometre is now less favourable than in the case of rail. It is clear that for small loads and short distances is always better the road transport, but it would be interesting to create a network of freight by rail, for large distances and medium and large loads, coupled with an initial and final 
road transport using intermodal transport.

To make an efficient network combining various modes of transport need major investments are made, and that large companies begin to rely more on rail transport.

Therefore, there remains a long way to go, because the logistics are complex and costly investments. However, you can take advantage of the use of freight transport by rail to economic and environmental level.

\section{REFERENCE}

Community of European Railway and Infrastructure Companies (CER). Rail Freight Status Report 2013.

Comisión de las Comunidades Europeas (2001). Libro blanco. La política europea de transportes de cara al 2013: la hora de la verdad.

Fundación de los Ferrocarriles Españoles. Informe 2011. Observatorio del Ferrocarril en España. 2012.

ADIF. Declaración de red. 2013.

Observatorio de costes del transporte de mercancías por carretera. Ministerio de Fomento.

Ministerio de Fomento. (2010). Plan Estratégico para el Impulso del Transporte Ferroviario de Mercancías en España

Aparicio, F., Arenas, B., Gómez, A., Jiménez, F., López, J.M., Martínez, L., Páez, F.J. (2008). Ingeniería del Transporte. Ed Dossat.

Comisión de las Comunidades Europeas. (2006). La logística del transporte de mercancías en Europa - la clave para la movilidad sostenible.

Daniel Álvarez Mantarás, Pablo Luque Rodríguez. (2003) Ferrocarriles, ingeniería e infraestructura de los transportes. Universidad de Oviedo. ISBN: 9788483173654.

Sanz Bobi, Juan de Dios; Sanz, Isaac; Romero, Jose Javier; Loiero, Roberto; Brunel, Juan Andrés, Tafur, Javier. "TOOL TO ESTIMATE THE RAILWAY INFRASTRUCTURE BUILDING COSTS AND ITS ASSOCIATED TRAFFIC FLOW CHARACTERISTIC”. World Congress on Railways Research. WCCR2013. SidneyAUSTRALIA. 20-27 November.

Íñigo Peñaranda, Joan Carles Enguix, Jordi Mas. (2013) Transporte ferroviario de mercancías. Marge books. ISBN: 9788415340805.

Comisión Europea. (2011). Libro blanco. Hoja de ruta hacia un espacio único europeo de transporte: por una política de transportes competitiva y sostenible.

Martín Cañizares, $\mathrm{M}^{\mathrm{a}}$ Pilar et al. Herramienta para el dimensionamiento de la red para el tráfico de mercancías. Investigación FFE. Memoria de artículos, publicaciones y conferencias 2009-2010. 
Baumgartner, J.P. Prices and Costs in the Railway Sector. Laboratoire d'Intermodalité des Transports et de Planification. École Polytechnique Fédérale de Lausanne, Enero 2001.

ADIF. CIRTRA 2011. Enero 2012.

Vicente Rallo Guinot. (2008). Costes del transporte por ferrocarril. Una primera aproximación para su estudio sistemático. Fundación de los Ferrocarriles Españoles.

IDAE. Factores de conversión energía final-energía primaria y factores de emisión de $\mathrm{CO}_{2}$. Diciembre 2012.

Ministerio de Fomento. Corredor Ferroviario Mediterráneo. Octubre 2011.

Invensys Rail Dimetronic. Sistema ASFA.

ADIF, Estudio del Corredor Ferroviario Mediterráneo. Marzo 2011.

International Union of Combined Road-Rail Transport Companies, Nuevo marcaje para las unidades de carga intermodales en Europa. Mayo 2011.

International Union of Combined Road-Rail Transport Companies, EN 13044 ILU-Code and Codification Plate. Noviembre 2011.

www.renfe.com/empresa/mercancias

www.contrenrenfe.com

www.irionrenfe.com

www.pecovasa.com

www.multirenfe.com

$\underline{\text { www.adif.es }}$

www.newopera.org

www.innotrack.net

www.ecotransit.org

www.sustrail.eu 